\title{
THE NATURE OF THE CHURCH; AN ACCOUNT OF A RECENT CONTROVERSY.
}

AdOLF HaRNack. Entstehung und Entwickelung der Kirchenverfassung und des Kirchenrechts in den swei ersten Jahrhunderten. (J. C. Hinrichs'sche Buchbandlung, Leipzig, I9ro.)

The Constitution and Law of the Church in the first two centuries, by Adolf Harnack, translated by F. L. Pogson, M.A., edited by H. D. A. Major, M.A., Vice-Principal of Ripon Clergy College (being vol. xxxi of the Crown Theological Library). (Williams \& Norgate, London, I910.)

What is the Catholic Church, and where did it come from? The book that is named at the head of this notice is a contribution by Dr Harnack to the discussion of this ancient, but living, problem. How difficult a question it is to answer in any way that is likely to find acceptance all students of theology know well. The difficulty seems to arise from the particular combination of imagination and fact that must needs find a place in the conception of a thing which claims to be heavenly, supernatural, and yet at the same time enters into the affairs of men in the most concrete way possible. There are two easy paths to a solution and they both arrive at their goal by the same method, by dichotomizing these two elements of imagination and fact. Those who take the one say that the Church is a definite self-contained collection of people, known to everybody by certain signs and common rites; those who take the other say that it is the company of those whom God has chosen, whose number and whose names are known to Him alone. This method, though apparently simple, is extremely difficult to sustain in practice. For the believers in the visibility of the Church may constantly be found passing over almost insensibly into the other point of view, and vice versa. Dr Harnack's book is an extremely important one for all who are interested in this problem. It marks a stage in the discussion, and we may be very grateful that it has been made accessible in English. It is translated partly by the late Mr F. L. Pogson, who did such good work in this way, and partly by Mr Major. The translation is very well done, and in this respect the volume compares favourably with"many of the larger volumes in the Theological Translation Library. It is right, however, to protest against the meaningless expression 'centre round' (p. i 8). The work consists of four sections. (I) Rise and developement of the Organization and Law of the Church in the first two centuries; (2) Primitive Christianity and Catholicism ; (3) The fundamental Confession of the Church (the Trinitarian formula); (4) History of the use of the word Gospel in the early Church, followed by a detached note on the meaning of 'Word', 'Word of God', 'Word 
(Words) of Christ ' in the N. T. Of these the first two occupy considerably more than two-thirds of the book. The first section is an enlarged reissue of the article 'Verfassung, kirchliche usw.', in volume $x x$ of Hauck-Herzog's Realencyclopädie für Theologie und Kirche (3. Auflage). This article appeared in 1908. In 1909 the Proceedings of the Königlich-Sächsische Gesellschaft für Wissenschaften (Philol.Histor. Classe, Bd. 27, H. 3) contained an article by the veteran scholar Rudolf Sohm called 'Wesen und Ursprung des Katholizismus', which was really a strong attack on Harnack's position, while recognizing the great value of his work. In this article Sohm reaffirms, though in a slightly modified form, the view he gave to the world in the first volume of his Kirchenrecht ( 1892 ), and takes up once more the problem raised at the beginning of this notice, 'for the appearance of the Catholic Church in the course of the second century is the most important occurrence in the whole of Church History.' To it is due not only Catholicism, but also the Reformation, since this is a reaction against the Catholic principle.

But the explanation of its appearance still awaits demonstration. Two facts are clear. (I) Primitive Christianity was not Catholic. This has been shewn by Protestant theologians. (2) Yet Catholicism is a continuation of primitive Christianity, and one which, while it encounters opposition, yet establishes itself with all the ease of a natural developement. And so there must have been in primitive Christianity the seed from which Catholicism has sprung. What is it ?

The answer of Albrecht Ritschl in Die Entstehung der altkatholischen Kirche (2. Aufl. 1857), developed with great insight and learning by Harnack, holds the field in Protestant circles. Sohm's version of this view is that Gentile Christianity ('Heidenchristentum') is the source. It was its theological dogmatic character, which was fundamentally incapable of grasping the true nature of the Gospel, as it was seen and preached by Paul not exactly alone, but certainly in a way far in advance of that of the other Apostles. The spiritualized Old Testament was seized upon by the Hellenic element, and so the Glad News was turned into a New Law, and Faith into a Teaching. The Hellenization of the Gospel is Catholicism. On this theory the great fact is that the idea of the New Birth and of Justification by Faith was left on one side. Everything else is result, such as the settling of the true faith through the Apostolic teaching power of the Bishops, and the relaxing of moral demands through the priestly power of the keys. It was not the developement of organization, but Hellenizing transformation of the Gospel, that was the strength of Catholicism. Readers of Harnack will recognize him in this picture, but it will not be surprising if they feel there is an element of caricature. Sohm goes on :-Intellectualism and Moralism are elements in Catholicism, but they are not Catholicism. 
For Orthodoxy and 'Aufklärung' have played their part in Protestantism as well. Again, in Puritanism great importance was ascribed to the Old Testament, another 'Catholic' tendency. The truth is that the distinctive mark of Catholicism is to be found in the practical, not in the theological sphere; it is the Infallible Church, i.e. 'Kirchenrecht', whereas the basal idea of Protestantism is freedom. (This one feels bound to point out is not the case with the original Protestants, Luther or Calvin, who, being leaders of a religious movement, naturally appealed to authority.) Sohm's quarrel with Harnack is that although in the third edition of the Dogmengeschichte he recognizes his main point, when he says (p. $304 \mathrm{n}$. I) the whole essence of Catholicism is to be found in the deification of tradition, yet he has left the rest of his treatment as it stood. Moreover, the prevailing teaching has remained unaffected, $c f$. v. Schubert's otherwise admirable Grundzüge (1909); and Harnack is still unregenerate, witness his article in Hinneberg's Kultur der Gegenwart (1,06), and the still more recent article in the Realencyclopiddie (the one here under review). Sohm proceeds to expound his own view as to the true nature of Catholicism. He starts from the distinction familiar to Protestant thought between the Church as a legally organized body ('Kirche im Rechtssinn') and the Church in the religious sense ('Kirche im Sinn des Glaubens'). The one is the product of men, the other the creation of God. It was Luther's discovery that these are to be set sharply over against one another. Calvinism and the 'Aufklärung' between them, however, accustomed the world to the idea, which is now universal, of the Church as a religious society ('Kirchengesellschaft'). The primitive Church is constantly spoken of, as though it shared this view, and stood already at the point of view of the 'Aufklarung', which is absurd. Neither is it true that it was conscious of the opposition between the Church in the religious sense and the Church in the legal sense (Kahl). It knew only the Church in the religious sense. There were no local officials, no locally organized churches, only the Church of Christ. It is always the whole that is present. There are no parts, no communities. The opposition was not clearly seen by Augustine or Wyclif, or anybody indeed before Luther, who discovered it, and proclaimed the invisibility of the Church, no 'verzweifelte Idee', as Harnack asserts, but the mightiest of all that have appeared in all Church History. It is the foundation of Protestantism. Conversely the essence of Catholicism lies just in this fact, that it does not distinguish between the Church in the religious sense and the Church in the legal sense. The Church of Christ is for it a legal organization; the life of Christendom with God is ruled by the Catholic Canon Law. There is only one Christianity on the earth, that which is loyally and legitimately the continuation of the Apostolic Church, which is the 
creation of Christ. And then follows a sketch of a view which is recognizably that of the modern Roman Catholic Church, though again with a slight touch of caricature.

It was not to be expected that Harnack would leave such an onslaught, especially one so able, unanswered. The second section of the book that is named at the head of this article, bears the sub-title " "Spirit" and Law : a criticism of Rudolf Sohm's Wesen u. Ursprung des $K$.' Harnack had already in the introduction to his article in the Realencyclopidie paid Sohm the compliment of saying that his theory stood out from all others that were the result of modern historical criticism by its selection of the right starting-point, and by its logical developement. He admits that he has learnt much from it. And indeed there are so many points in common that it is not quite easy to see at once wherein the difference lies. Both agree in rejecting the (Roman) Catholic definition of the Church, in affirming its primitive non-Catholic character. It was not Protestant, we have found Sohm maintaining. Harnack in his turn asserts that the Reformed Church ' no longer possesses any connexion with the constitution of the Church of the first and second centuries' (Verfass. p. 120). Both agree in recognizing the germs of Catholicism in the primitive community. Sohm claims Harnack as accepting his theory when he says 'the com-

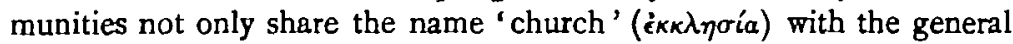
community of God, but every one is a finished picture of the Church as a whole, and indeed its consummation (for the whole is in the part and not merely the part in the whole)' (Verfass. p. 35, cf. Sohm, $W$. u. $U . d . K$. p. $\left.{ }^{6} 65\right)$. But there is really a profound difference. Sohm approaches the entire question from the point of view of a legal theorist rather than from that of the historian of thought, which is the outlook of Harnack. It is natural then that the former should find the explanation of the phenomena in the practical sphere, the latter in the dogmatic. But the difference between them goes further than this. Sohm's theory is made to explain everything, and it does so by the short and easy method of dichotomizing referred to above. $\mathrm{He}$ is logical and consistent. All's law or all's love. He commends the compelling logic (' die $z$ wingende Logik') of Luther in utterly giving up the Visible Church. He cannot speak contemptuously enough of Th. Kaftan, for accepting the 'religious' view of the Cburch in theory, and yet venturing to assert that the legally organized Church is the Body and Organ of Christ. But the truth is that Kaftan's theory is only finding itself tempered by experience of concrete fact, and practical religious need.

Then again, Sohm's slighter grasp of historical perspective is reflected in the way in which.he speaks of Catholicism, by which he seems to

VOL. XIII. 
mean always the form which it took in the West, and especially that

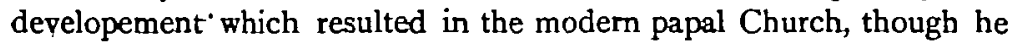
does in passing admit that a different state of things is to be found in Greek Catholicism, where there is no 'Statthalter Christi'. Harnack on the other hand points out that if you are going to say that the essence of Catholicism consists in making the actual visible Church regarded as a legal entity equivalent to the Church of Christ, you are bound to ask which Catholicism is meant. For that of the year A. D. 200 cannot be identified with that of the opening years of the twentieth century without qualifications. 'No doubt the same elements are present, but the proportions have changed, and this change of quantity, as always in history, has produced changes which seem to be qualitative, and really are qualitative. For the Catholicism of the period about A. D. 200 it is not true to say that the Church as a legal body was already identified in every respect with the Church in the spiritual sense (this does not apply even to Cyprian)' (Verfass. pp. I73, I 74). This leads me on to the principal point which Harnack makes against Sohm, which, indeed, the latter is bound to admit, namely, that from the first there was a certain identification of the Church in the spiritual sense with the actual visible Church. The New Testament bristles with the evidence for this, once the origin of the word $\varepsilon_{\kappa \kappa} \lambda_{\eta \sigma i a}$ is seen. It was pointed out in Cambridge as long ago as 1889 in the lectures of Dr Hort (afterwards published under the title of 'the Christian Ecclesia') that it is really equivalent to להT, or God's Israel. That is, as Harnack says: 'They were something more than a body of pupils, or even a synagogue. They were a community called of God, and ruled by the Spirit, i.e. something entirely new, but at the same time a realization of the old ideal.' Sohm seems to acknowledge this, and yet to fail to see its real effect. For the truth is that the early community was composed of individuals who had not simply passed through a private experience of redemption, but conceived of themselves also as under a theocracy, which was being brought to its full developement by Jesus. They were actually the People of God. Harnack has no difficulty in shewing that this involved the possession of powers of jurisdiction by the community over its members, powers for the exercise of which there is plenty of evidence, both in Acts and in the Epistles. And these powers are not used in any apologetic way, or with any other suggestion than that they are the exercise of natural rights inherent in the People of God. Harnack had already in rgoz (Mission und Ausbreitung p. 309) given an account of the primitive faith in this matter. He shews there that the Christians in any particular place recognized themselves as an image ('Abbild') of the whole Church of God, and yet were at the same time a Kultverein, a community organized for worship. This Sohm says is 
impossible and contradictory (Wesen und Urspr. p. 366). But Harnack is able to shew that these two contradictory elements were as a matter of fact present to the primitive consciousness. And just because of this the community exercised the powers of jurisdiction to which I have referred. For what seem like contradictions are inevitable if we are to think adequately of a thing which claims to have both an invisible and a visible existence.

Harnack is not content with shewing the incompatibility of Sohm's view with the ideas of the first age. He prefaces the discussion of the point with an examination of the inevitable consequence of allowing Sohm's initial dichotomy. I give it in his own words. 'It is impossible to see, if we simply eliminate everything eartbly from the nature of the Church, how the Church can then be anything but a mere idea, in which each individual Christian in his isolation believes. Even so, this idea may be efficacious and powerful, but this is not a Church, but a numerus praedestinatorum et credentium, who can have no connexion with one another, and who resemble a number of parallel lines, which meet in infinity and not before.' So far is this from being the case that the social and corporate element is in Christianity no afterthought, but of its very nature, and a thing that enters into the very sublimest conception of the Church (Verfass. p. 148). This is so, although the foundation of the Church cannot be proved to have been part of the plan of Jesus. Protestant and Catholic theologians alike have made too much of this. Yet they are substantially right. For it was founded by the Twelve whom He appointed.

I have taken Harnack's controversy with Sohm first, although it does not come first in the book or occupy the largest part of it, because it really has logical priority. If there is no visible Church, in some real way the representative of the invisible, the whole question of organization occupies an entirely different position. Many discussions upon such subjects as Orders, which are really subsidiary, are vitiated, because the different parties have not first faced this fundamental question.

In the enlarged article from the Realencyclopadice, the first section of the book, Harnack gives a more thorough account than he has done elsewhere (Apostellekre, Mission u. Ausbreitung, \&c.) of what can be learned from the documents as to the primitive organization of the Church. It is a masterly and balanced account, agreeing in the main with positions already put forward by him.

It is impossible to go through it in detail. I can only single out points here and there. Section 4 brings out in an admirable way the number of different authorities that existed in the primitive Community, the Twelve, the Spirit, the O.T., the words of the Lord, \&c. In speaking of the laying-on of hands, the method of appointment to 
the service of the community, the remark occurs: "The "laying-on of hands" was certainly "sacramental", for what rites, new or old, could help being sacramental in a community which had the Holy Spirit actively working in its midst?' (Verfass. p. 20). One thing that stands out clearly is the central position of the Apostles, and the universal character of their authority. This is from the start a makeweight against the 'democratic' and independent tendencies which were also really there.

Harnack's theory as to the relation of the Apostles to the local officials is well known, and is mainly based on the evidence of the Didache, and the silence of Ignatius with regard to the Apostolic character of the episcopal office. The Apostle and the prophet are universal in their range, the Bishop (Presbyter) and Deacon are local. The latter could be chosen and appointed by the community (Did. xv Xєبoтоr' $\sigma a \tau \epsilon$, \&c.). It is possible to doubt, however, whether this passage will bear this weight. The whole question of what is meant by 'charismatic' is extremely hard to settle in such a way as to exclude an Episcopus. Again, it is difficult not to feel that the Bishop is made too much a local official, representing the particular community (Verfass. p. 73). Is he (they) not also the representative of the Universal Church to the particular.community? That this was the case at a later date is recognized (Verfass. p. 86).

Is there not here something in Sohm's objection (Wesen und Ursprung d. $K . \mathrm{p} .3^{62}$ ) when he says that the modern mistake is to begin with the local community, a view which really takes its rise in that of Vitringa (r6g6), who supposed it to be modelled on the Jewish synagogue? With Heinrici begins the more modern theory of Hellenistic influences, which was maintained by Hatch (whose Organization is according to Sohm much too highly praised: 'Das Buch hat eine elegante Form, aber einen durchaus unklaren Inhalt'). Harnack has followed in the same path. The episcopal office on this theory, beginning as a local affair, gradually becomes an office of the universal Church, much in the same way as Churches originally independent gradually federated. This is not quite fair to Harnack, who certainly is far from thinking that the episcopate sprang from imitation of Pagan organizations. But surely a necessary corrective to his general view of the episcopate is found in Sohm's further remark: 'The office-bearers of the local Christianity, Bishops and Deacons, were thereby enrolled among the organs of oecumenical Christianity,' i. e. did not the Bishops stand for the universal Church to their community, as well as for their community to the rest of the Church ?

Were there many Bishops or was there one? The outstanding fact is that in the period from Vespasian to Ignatius, with the exception of 
the Epistles of Ignatius, there is no certain trace of a monarchical Bishop, whereas in the succeeding age, that of Antoninus Pius and Marcus Aurelius, that office, together with the organization that goes with it, is to be found everywhere in the Church, in Antioch, Rome, Corinth, Greek and Asiatic cities, Crete. The sketch of the developement which follows in Harnack's article would almost inevitably lead one to compare the account with the extremely similar one given by Duchesne, the other authority perbaps most qualified to speak at the present time, in his admirable chapter, 'L'Épiscopat', in his Histoire ancienne de I'Église (tom. i), if Harnack had not himself drawn attention to it. $\mathrm{He}$ remarks in a footnote to p. 73 that the difference will appear to be 'minimal'; but that it is a real one is shewn by Duchesne's remark that whether the communities had one bishop at their head, or whether they had several, the episcopate gathered up ('recueillait') the Apostolic succession.

The difference lies in the fact that.whereas Harnack thinks (with the Didache at his back) that at the very beginning the 'bishops' were appointed ('ordained') by the community, Duchesne thinks that they were appointed by the itinerant 'apostles'. The New Testament certainly provides at least as much evidence in support of this view.

With regard to 'Monepiscopacy' and its origin Harnack and Duchesne agree very much. As Harnack points out, we lack almost all direct information, and he bids us remember the late Dr Salmon's words: 'If the original constitution of the Church was not the same as in the time of Irenaeus, it must at least have been capable of an inner developement to the later form, and, indeed, in the form of quite gradual changes, called forth by causes universal in their nature.' Does not the adoption of this saying mark the conclusion of the author on a question on which in earlier discussions he had abstained from giving an opinion? (Cf. Chronologie i 193 Anm. 3.) Harnack supposes there was from the start a kind of informal monarchy, and Duchesne points out how although there appear to be no traces of 'monarchical' episcopacy in the 'Shepherd', yet we know from the Muratorian Fragment that the author's own brother did as a matter of fact occupy that position at Rome. Altogether it seems most reasonable to suppose that in some way or other 'monarchical' and 'collegiate' episcopacy went on from the beginning side by side in the same community.

Harnack's discussion of the rather fanciful form that the idea of Apostolic Succession took at the end of the second century, i.e. that each of the principal sees had an Apostolic founder, is interesting. ' $\mathrm{He}$ shews that such an idea was natural to those acquainted with Roman law, and with Judaism. But its rise in the Church was not due to these influences. The explanation is rather to be found in such, passages as 2 Timothy ii 2 . It was a guarantee that the true, i. e.; 
primitive, faith was preserved. For this connexion with the Twelve is necessary. The stages preparatory to the developed idea of Irenaeus lie. far back, and 'the tradition that the apostles had appointed the officials of the Church is partly correct'. There is one remark, however, in this connexion which may fairly be criticized. In speaking (Verfass.

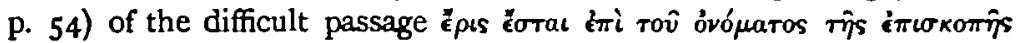
(I Clem. xliv) Harnack says there is no question here of Apostolic Episcopal succession. This may be true, in a sense; but in face of

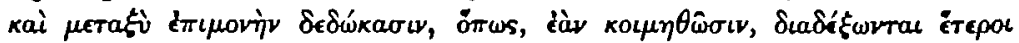

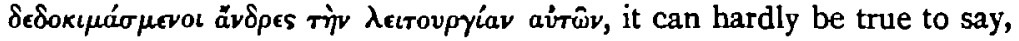
as he does, that there is no question of succession at all. Whether we

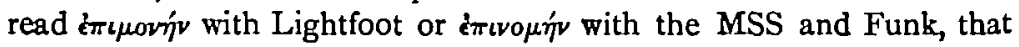
point is left untouched.

There is another passage in the letter of Clement, of which Harnack's interpretation is open to question. He speaks (Verfassung p. 53) of Clement's comparison of the order of the Christian Church with that of the Old Covenant in the well-known passage I Clem. xli as a momentous ('verhängnisvoll ') first step, and as something new. He seems to say, too, that this comparison is a fruit of the $\pi \lambda$ ciovos $\gamma v$ wow spoken of at the end of the section. Both these statements are rather surprising. ' Surely this allegorical or figurative employment of the events or laws or religious language of the Old Testament in reference to the life of the New People is deeply embedded in the New Testament. It is hardly even original in its application to the particular question of ecclesiastical order. Harnack admits that the beginning of such an application is to be found in I Cor. ix 9 and I Tim. v 18 . I Cor. ix 13 is more to the point, and might not Acts i 20 be added ? Surely such a step was inevitable for men who could say-with the author of the Epistle to the Hebrews, 'We have an Altar, whereof they have no right to eat who serve the Tabernacle'. The whole conception is really

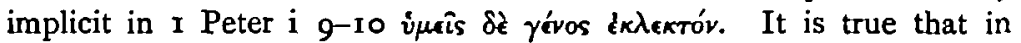
later times the comparison between the Chtistian priesthood and that of the Jews is treated as though the former were the exact counterpart of the latter, and is conceived of in quite a legalistic way. But is not Clement disclaiming such a view ? He treats the Jewish institution as an allegory of the Christian. But this is not introduced as though it were a new discovery of his. Sohm certainly speaks as though it were. Harnack in his Realencyclopädie article almost says so, though later in the book (p. 159) he speaks more cautiously of its coming before our notice here for the first time. 'You see, brethren,' Clement says, 'we have been endowed with greater knowledge, so much the more are we exposed to danger.' It is not the pride of the Roman community that is reflected in these words, but the solemn responsibility which the 
Christian minister feels at being entrusted with a ministry of a deeper spiritual import than its earlier and in its way true analogue, the priesthood of the Old Covenant. That, I venture to submit, is the true interpretation of these words.

Harnack is in this book, as almost almays, so refreshingly free from traditional opinions that one is the more surprised to find him still saying that the use of the designation 'priest' was the 'folgenschwerste' title of the officials, as though it really involved the introduction of a new element (Verfass. p. 83). The organization of the Church is often spoken of as though it were primarily a question of government. There is no doubt that from the first, as Harnack makes clear against Sohm, jurisdiction over the moral life of the community was energetically exercised, and in a large measure through its officials, and further that this did result in giving to them a greater importance in the whole working of things. But it is important to realize that the 'matter', so to speak, of their jurisdiction was far more the conduct of public worship and its requirements. And, indeed, the high standard of morals demanded from the community arose very largely from a desire to preserve the holiness of the 'Mysteries'. On this point there is a much larger measure of agreement between the two writers. Sohm supposes that from the first there were two assemblies, one for edification, and one for Eucharistic worship, and that it was this latter which made the officials important. Harnack will not allow that the use of priestly language is mainly to be explained as imitation of the Old Testament, or borrowing from Judaism. [This is interesting, if compared with his remarks on I Clement above.] To adduce Gnostic or heathen influence is irrelevant, for 'die grosse Kirche' did not in the second century follow either Gnostic or heathen leaders. The root of the specific ecclesiastical priesthood is much more to be found in those essentially sacrificial ideas which clustered round the Lord's Supper. And these began very early, e.g. I Clem. xliv $\pi \rho \circ \sigma \phi e^{\prime} \epsilon \iota v$ rà $\delta \hat{\omega} \rho a$, and the use of Quvia in the Didache. So far Harnack. But the question arises here whether we cannot trace them farther back still. It may be true that the use of the word 'Sacerdos' appears for the first time in Tertullian; but is it not already implicit in St Paul, in $I$ Corinth. $\times 2 \mathrm{I}$, where

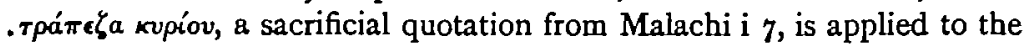
Eucharist, and definitely used as a practical equivalent for tuocaorifocov?

These are criticisms of details. All students of the subject must needs be grateful for a book which presents the early history of a thorny subject in so passionless a way, and with such a wonderful combination of insight and detachment. In his main controversy with Sohm I feel that Harnack is right. Sohm wishes to cut the knot. But he, too, has. done a service; not only, as Harnack implies, by his insistence upon his 
theory in such a way that its avoidance of important facts becomes clear, but also because there is a large element of truth in it. It is true in the first place that the idea of the Invisible Church has played and does play a great part in conceptions of the Divine Society, Catholic as well as Protestant. And, secondly, what Sohm calls the 'Legal Church' is really part of the explanation of Catholicism. 'Catholicism', according to Harnack, ' is the preaching of the One God, and the Crucified and Risen Lord and Saviour Jesus Christ, carried over into the Hellenic world of thought, and worked out as a philosophical doctrine.' To this, to get completeness, one must add the conception of the Church as a legal body, led by the Episcopate (Verfass. p. 184 ). But surely this idea of the Church as 'Rechtskorper' in Sohm's sense, which Harnack is here adopting, runs right back to the beginning. The episcopally-led Church is just the form that the 'People of God', the 'true Seed of Abraham', took when it came out into the Gentile world. And the announcement of the true $\ell_{\kappa \kappa} \lambda \eta \sigma^{i} a$ was as much a part of the primitive preaching (taking St Paul as primitive) as the One God or the Crucified and Risen Saviour. Harnack has spoken true words in this book as to the inevitableness of the Catholic developements, the developements which made the Church of A. D. 200 what it was, and took place not only in the sphere of dogma, but also in that of organization. The changes of organization were not afterthoughts patched on, but the growth of an original element ; and it is this element which, if it does not account for Catholicism quite as completely as Sohm would have it do, yet has been one of the most essential things in its fibre. It is this Catholic element, which is capable of degradation indeed, and may be crudely emphasized, that nevertheless is one of the sources of the Church's most vigorous life, and this not only in the Roman Catholic communion, and the ancient Churches of the East. It has also remained embedded in the consciousness of those communions in the West which have at various times broken with the Papal government, sometimes even when, as in the case of the bodies founded by Luther and Calvin, a resolute effort was made to cut off the past. For there, too, there are often clear marks of this element, which consists fundamentally in the assertion that the Israel of God is on earth still, working out His plans, possessing and manifesting • His revelation, incorporating men in $\mathrm{Him}$, through membership in itself. And the blame for this, if blame there be, is, partly at any rate, to be awarded to the 'canonical ' character of the New Testament, in itself a 'note' of the Catholic Church, as Harnack witnesses. For that has involved the acceptance as authoritative of the idea, so prominent there, of the. inextricable, though indefinite, connexion between the 'Invisible ' and the 'Visible' Church.

A. S. Duncan Jones. 